\title{
СУЧАСНІ ДОСЛІДЖЕННЯ ПРОБЛЕМИ ПРОФЕСІЙНОЇ ПІДГОТОВКИ МАЙБУТНІХ ВИХОВАТЕЛІВ У ПЕДАГОГІЧНІЙ ТЕОРІЇ ТА ПРАКТИЦІ
}

\author{
(C) Прокопенко I.Ф., 2019 \\ https://orcid.org/0000-0002-1190-852X \\ (C) Мкртічян О.А., 2019 \\ https://orcid.org/0000-0003-4962-3631 \\ http://doi.org/10.34142/2312-2471.2019.61.17
}

\begin{abstract}
Сучасні умови, орієнтація суспільства на демократичні засади, модернізація системи дошкільної освіти (різноманіття форм дошкільного виховання, варіантність навчальних програм) зумовлюють необхідність змін 8 системі підготовки вихователів. У статті висвітлено актуальну проблему підготовки майбутніх вихователів до професійної діяльності з дітьми дошкільного віку, яка знайшла відбиття в багатьох сучасних науковопедагогічних дослідженнях. Проведено аналіз теоретичної бази дослідження, зокрема, найбільи відомих учених у галузі професійної підготовки майбутніх вихователів закладів дошкільної освіти таких, як Г. Аніщенко, Г. Бєлєнької, I. Бутенко, О. Вашак, С. Гаврилюк, Н. Давкуш, І. Дичківської, А Залізняк, С. Петренко, Т. Філімонової, Т. Танько та ін. Мета статті: на основі аналізу науково-педагогічних джерел визначити суть поняття «підготовка майбутніх вихователів», розкрити роль та значення підготовки фахівцівв у професійній діяльності в закладах дошкільної освіти. У процесі дослідження використано такі методи: аналіз, порівняння, узагальнення для вивчення наукової літератури з окресленої проблеми, щзо дозволило визначити суть $і$ особливості підготовки майбутніх вихователів у закладах вищої освіти (ЗВО). Зазначено, щуо нині значна увага приділяється проблемі підготовки студентів факультету дошкільної освіти, адже головною постаттю, від якої залежить навчання, виховання та розвиток дітей дошкільного віку, $\epsilon$ вихователь закладу дошкільної освіти (ЗДО). Визначено та уточнено суть поняття «підготовка майбутніх вихователів» та розкрито зміст професійної підготовки студентів дошкільної освіти у 3 ВО та здатності, якими вони мають володіти для успішної професійної діяльності. Комплексний аналіз проблеми підготовки майбутнього вихователя в науковій психолого-педагогічній літературі свідчить про те, щзо у сучасних умовах система підготовки майбутніх фахівців дошкільної освіти розглядається вченими як багатофакторна структура, головне завдання якої полягає в набутті кожним студентом особистісного сенсу діяльності, формуванні професійної майстерності, постійно зростаючий інтерес до роботи з дітьми та їхніми батьками, а також у розвитку успішності в діяльності, на основі якої по-новому вирішуються питання підвищення ефективності виховання у ЗДО.
\end{abstract}


Ключові слова: майбутні вихователі, освітній процес, підготовка, дошкільна освіта, заклад дошкільної освіти.

\section{Prokopenko I.F., Mkrtichian O.A. Modern Research of the Problem of Professional Training Future Educators in Pedagogical Theory and Practice}

Modern conditions, the orientation of a society to democratic principles, the modernization of preschool education system (variety of preschool education forms, the variability of educational programs) necessitate changes in the system of educators' training. The article highlights the current problem of preparing future educators for professional activities with preschool children, which is reflected in many modern scientific and pedagogical researches. The authors analyze the theoretical basis of the study, in particular, the most famous scientists in the field of professional training future educators of preschool institutions such as G. Anishchenko, G. Belenka, I. Butenko, O. Vashak, S. Gavrilyuk, N. Davkush, I. Dychkivska, A Zaliznyak, S. Petrenko, T. Filimonova, T. Tanko and others. The purpose of the article is to determine the essence of the concept «training future educators», based on the analysis of scientific and pedagogical sources, to reveal the role and importance of training in professional activities in preschool education. In the course of the research the following methods were used as analysis, comparison, generalization for studying the scientific literature on the outlined problem, which allowed to determine the essence and features of training future educators in institutions of higher education. It is noted that nowadays a lot of attention is paid to the problem of training students of the Faculty of Preschool Education, because an educator is the main figure on whom the education, upbringing and development of preschool children depend. The essence of the concept "training future educators" is defined and clarified and the content of professional training preschool students in institutions of higher education, and the abilities which they must have for successful professional activity are revealed. A comprehensive analysis of the problem of training future educators in the scientific psychological and pedagogical literature shows that in modern conditions the system of future preschool specialists' training is considered by scientists as a multifactorial structure, the main task of which is to acquire for each student a personal meaning, professional skills, constantly growing interest in working with children and their parents, as well as in the development of success in the activities on the basis of which in a new way to address the issues of improving the effectiveness of education in preschool education institutions.

Keywords: future educators, educational process, training, preschool education, preschool education institution.

Постановка проблеми. Проблема підвищення якості дошкільної освіти є актуальною, оскільки найважливішим напрямом модернізації освіти в Україні $\epsilon$ підвищення іiі якості, приведення у відповідність зі світовими стандартами. Зміни в системі дошкільної освіти, обумовлені соціально-економічними процесами, відображаються на підготовці майбутніх фахівців у закладах вищої 
освіти (3ВО) до роботи з дітьми та вимагають змін у змісті освіти. Ефективність підготовки майбутнього вихователя залежить від рівня набутих знань, умінь i навичок, можливості застосування цих знань в умовах закладу дошкільної освіти (ЗДО), а також готовності до професійної діяльності.

Формування сучасної гармонійно розвиненої особистості (дитини) не може відбуватися без вихователів нового покоління 3 відповідним рівнем кваліфікації, вимоги до підготовки яких значно зросли. Слід зазначити, що в системі освіти дошкільна $є$ першою та основною ланкою і впливає на наступні рівні іiі розвитку. Тому підготовка майбутніх вихователів ЗДО, які володіють загальними та професійними компетенціями, є актуальною в галузі професійної освіти й взаємопов'язана від сучасних змін в дошкільній освіті.

Аналіз останніх досліджень і публікацій. В процесі проведеного аналізу наукової літератури та наукових доробок вчених, які досліджували проблему підготовки майбутніх вихователів в умовах 3ВО, зазначимо, що більшість 3 них процес підготовки здійснювали шляхом розробки та реалізації: науковометодичної системи (І. Дичківська [17;18]); модель (В. Бутенко [3;4]; О. Вашак [5;6]; С. Гаврилюк [9;10]; Г. Грама [13;14]; Н. Давкуш [15;16]; А Залізняк [23;24]; Н. Захарасевич [25;26]; С. Петренко [33;34]; Т. Філімонова [41;42]); педагогічні умови (В. Бутенко [3;4]; Е. Бахіча [1;2]; К. Віттенберг [7;37]; С. Гаврилюк [9; 10]; Л. Галаманжук $[11 ; 12] ;$ Г. Грама $[13 ; 14] ;$ Н. Смельянова [21;22]; А. Залізняк [23;24]; С. Нечай [31;32]; С. Петренко [33;34]; О. Попович [35;36]; Т. Танько [38]; І. Трубник [39;40]; Т. Філімонова [41;42]); методику (Е. Бахіча [1;2]; К. Віттенберг [7;37]; Н. Смельянова [21;22]; Т. Книш [27;28]; С. Гаврилюк [9; 10];) технології (С. Дяченко [19;20]; Н. Миськова [29;30]).

Виділення невирішених раніше частин загальної проблеми. Однак нині відсутні наукові дослідження, які ураховують сучасні каталізатори змін в парадигмі дошкільної освіти й відповідно сучасний стан підготовки майбутніх вихователів.

Формулювання цілей статті. Мета статті - на основі аналізу науковопедагогічних джерел визначити суть поняття «підготовка майбутніх вихователів», розкрити роль та значення підготовки фахівців у професійній діяльності в закладах дошкільної освіти.

Для досягнення поставленої мети використовували такі методи наукового дослідження, як: аналіз, зіставлення, узагальнення для вивчення наукової літератури з окресленої проблеми, що дозволило визначити суть і особливості підготовки майбутніх вихователів в сучасних умовах.

Виклад основного матеріалу. Висвітлення основних питань, до кола яких входять насамперед категорії «підготовка майбутніх вихователів», що $\epsilon$ засадничим для розуміння порушеної проблеми, забезпечить обгрунтоване окреслення термінологічного поля дослідження й визначення суті та змісту поставленої проблеми.

Вивчаючи проблему підготовки майбутніх вихователів дошкільних закладів до інноваційної педагогічної діяльності, І. Дичківська підготовку майбутніх фахівців бачить успішною за умови іiї організації у спеціально 
створених середовищах. Так, майбутні вихователі отримують основну інформацію про інноваційні процеси в межах 3ВО, у межах організаційних форм формуються інноваційні уміння квазіпрофесійної діяльності, а в зовнішньому середовищі набувають досвіду відтворення чинних інновацій у реальних умовах професійної діяльності (створення та реалізація авторських інноваційних проєктів, їх презентація, захист та популяризація серед педагогічної спільноти) (Дичківська, 2018).

Так, В. Бутенко, досліджуючи проблему підготовки майбутніх вихователів до формування здоров'язбережувальної компетентності дошкільників засобами ігрової діяльності, характеризує як процес опанування необхідними теоретичними та методичними знаннями за професійною спрямованістю, як розвиток якостей та здібностей особистості щодо формування здоров'язбережувальної компетентності дошкільників засобами ігрової діяльності (Бутенко, 2018).

В кандидатській дисертації «Підготовка майбутніх вихователів дошкільних навчальних закладів до професійної діяльності в полікультурному середовищі Криму» Е. Бахіча розглядає підготовку майбутніх вихователів як процес, що спрямований на формування компетентності майбутніх вихователів в межах суб'єктних і особистісних якостей дітей дошкільного віку. За допомогою сукупності певних педагогічних умов, що створюються в процесі підготовки майбутніх вихователів, в змісті навчання є інформація про культурні традиції народу, виконання практичних завдань надає можливість опанування методикою полікультурного виховання дітей дошкільного віку на засадах толерантності, а виховна робота забезпечує набуття майбутніми фахівцями особистого досвіду толерантної взаємодії і співпраці в полікультурному середовищі (Бахіча, 2011).

О. Вашак в науковому дослідженні «Підготовка майбутніх вихователів до екологічного виховання дошкільників на засадах етнопедагогіки» визначає поняття «підготовки» як процесу формування у фахівців здатності виховувати особистість в контексті науково-педагогічного напряму і досвіду народної педагогіки. Система підготовки майбутнього вихователя засобами екологічної культури є безперервною та міждисциплінарною, розв’язує проблеми навколишнього середовища та спрямовує особистість на гармонізацію відношень із природою, а також розвиває емоційно-ціннісну сферу дитини (Вашак, 2010).

За даними дослідження К. Віттенберг, підготовка майбутніх вихователів засобами інформаційно-комунікаційних технологій до навчання дітей іноземних мов розглядається як складова в процесі організації навчання у межах спеціалізації «англійська мова» 3 використанням інформаційнокомунікаційних технологій. Автор зазначає про те, що процес підготовки майбутнього вихователя є ефективнішим завдяки використанню інформаційнокомунікаційних технологій, комп'ютерних продуктів і послуг (змістовне наповнення розділів програми підготовки, онлайн-консультування батьків 
щодо навчання дітей іноземним мовам), а також введення іншомовної лінгводидактичної компетенції (Віттенберг, 2010).

Характеризуючи підготовку майбутніх дошкільних педагогів до комплексного використання творів пластичного мистецтва у вихованні старших дошкільників, Л. Галаманжук виділяє цільову, мотиваційну, змістову, процесуальну і результативну складові в системі підготовки фахівців, які безпосередньо впливають на формування знань, умінь, естетичного світогляду, i надає можливості вирішувати навчально-виховні завдання за допомогою творів різних видів світового пластичного мистецтва. Використання ж творів естетичної спрямованості в професійній діяльності формує естетичний світогляд дошкільнят, a також активізує їх «естетичне середовище» (Галаманжук, 2007).

Вивчаючи питання підготовки майбутніх вихователів до опанування методики формування в дошкільників елементарних математичних уявлень, Г.Грама доводить, що підготовка фахівця - це динамічне явище, що обумовлюється внутрішніми та зовнішніми чинниками, це процес, що передбачає засвоєння певного змісту професійно-педагогічної діяльності та способів його реалізації. Він спирається на актуалізацію та трансформацію математичних знань майбутніх вихователів з початкового етапу навчання у ЗВО до професійно орієнтованої діяльності в роботі з дошкільниками (Грама, 2010).

Ефективність роботи з формування в дошкільників математичних уявлень залежить від якісної методичної підготовки вихователя, високого рівня базових математичних знань, володіння математичною мовою, за допомогою якої дитина входить у світ математики, усвідомлюючи кількісні та якісні характеристики явищ довкілля. Використання базових математичних знань i умінь є підгрунтям для актуалізації й оволодіння діяльністю вихователя ЗДО. У процесі роботи з дітьми, при створенні асоціацій та переведення елементарних математичних уявлень в предметну й словесну форми відбувається відтворення математичних знань у свідомості та мисленні студентів (Грама, 2010).

Н. Давкуш у своєму дослідженні зазначає, що 3 урахуванням особливостей професійної підготовки педагогів-вихователів ЗДО до прогностичної діяльності, поняття «підготовка» трактує як блок теоретичних знань, життєвих установок особистості, якостей і практичних умінь фахівця у сфері прогнозування дій в навчальному процесі ЗДО, прагнення до планування власного самовизначення та особистісного розвитку дітей.

Професійна діяльність майбутнього вихователя визначається ціннісним цілепокладанням, обумовлена здійсненням системної діагностики у професійній роботі, плануванням педагогічних проблем і пошуку шляхів їх розв'язання, та упровадженням у процес управління розвитком, навчанням й вихованням дітей в ЗДО (Давкуш, 2011).

У вивченні питань підготовки майбутніх спеціалістів до розвитку у дітей комп'ютерної грамотності С. Дяченко пропонує шлях послідовного розгляду складових професійного розвитку вихователя в галузі інформаційно- 
комунікаційних технологій. Знання про інформаційні ресурси, технічні засоби навчання, набуття навичок роботи на комп'ютері та їх використання забезпечує здійснення вихователем професійної діяльності в закладі дошкільної освіти.

Так, сучасний вихователь розуміє місце комп'ютерних засобів, а також потребу у формуванні комп'ютерної грамотності населення та забезпечення інформаційними засобами ЗВО. Однак, впровадження IКТ в освітній процес ЗДО $є$ новою сферою професійної діяльності вихователя, і надає можливості фахівцю контролювати потік використання розвивальних комп'ютерних програм для дітей дошкільного віку, систематизувати, аналізувати їх та оцінювати (Дяченко, 2009).

Дослідження Н. Смельянової присвячене підготовці майбутніх вихователів до роботи над засвоєнням старшими дошкільниками народознавчої лексики. Національна система виховання, народна педагогіка та культура, національна освіта - основа світоглядних переконань людини, тому вивчення українознавчих і народознавчих дисциплін стає основною формою майбутніх фахівців. Опанування української мови як найважливішого засобу національного виховання забезпечує комфортне існування молодої людини в суспільстві та пізнання національного характеру (Смельянова, 2003).

Так, доцільне впровадження в освітній процес ЗВО (від дошкільної до вищої освіти) такі науки, як етнопедагогіка, етнопсихологія, етносоціологія, етнографія, фольклористика, в яких зберігаються загальнолюдські й національні цінності, генетичний код народу, а саме 3 раннього віку $\epsilon$ необхідним використання народознавчої лексики в процесі навчання рідної мови шляхом розширення словникового запасу дошкільнят. Під професійною підготовкою учений розуміє процес і результат діяльності майбутнього вихователя, який володіє запасом лінгвістичних, лінгводидактичних та народознавчих знань, умінь і навичок, що необхідні для успішного виконання його професійної діяльності (Смельянова, 2003).

А. Залізняк визначила підготовку студентів до роботи 3 батьками 3 морального виховання дітей як частину цілісного освітнього процесу ЗВО, як систему навичок, знань, умінь оволодіння якими сприяє розвитку здібностей студентів дошкільних факультетів, формуванню в них основ наукового світогляду та моралі, належної поведінки, а також підготовці до професійної педагогічної діяльності. Особливо важливо поєднання сімейного та суспільного дошкільного виховання, роль батьків у освітньому процесі, особливо в моральному вихованні старших дошкільників, оскільки головним соціальним орієнтиром є сім'я та ЗДО. Тому, майбутні вихователі у своїй роботі мають забезпечити високий рівень реалізації потенціалу сім'ї щодо морального виховання старшого дошкільника, сприяти підвищенню педагогічної культури батьків, активно впливати на взаємини між їі членами сім'ї (Залізняк, 2009).

Нині посилюється увага суспільства до освітнього процесу дошкілля, зростають вимоги до якості підготовки вихователів у організації ігрової діяльності дітей, формується активна та творча особистості. Науковий інтерес у контексті зазначеного має позиція Н. Захарасевич. В дослідженні «Підготовка 
майбутніх вихователів до рольової діяльності дітей у дошкільних навчальних закладах» учений наголошує на тому, що професійна підготовка - це організований, неперервний, планомірний та результативний, орієнтований на особистість, процес формування цілісної системи знань, фахових умінь, професійного мислення, становлення педагогічно значущих особистісних якостей, що стимулюватимуть їхній саморозвиток у самостійній педагогічній роботі (Захарасевич, 2018).

Підготовка вихователя у ЗВО передбачає вивчення специфіки рольової діяльності, враховуючи вікові та індивідуальні особливості дитини, використанні педагогічних прийомів організації навчання та виховання, методів, засобів розвитку різних компонентів рольової діяльності вихованців, організацію керівництва рольовою діяльністю дітей дошкільного віку (Захарасевич, 2018).

За дослідженням Т. Книш освіта майбутніх вихователів в галузі валеології, спрямованої на підготовку до виховання здорового способу життя у дошкільнят, $\epsilon$ процесом опанування валеологічної культури. Організація підготовки майбутніх фахівців у 3 ВО передбачає: розробку й впровадження уніфікованої програми, збільшення навчальних годин згідно 3 планом, зміцнення та збереження життя студентів. Тому, використання основ здоров'язбереження в процесі професійної роботи надає можливості майбутнім вихователям творчо вирішувати завдання валеологічного характеру 3 дошкільнятами (Книш, 2001).

Досліджуючи особливості підготовки майбутніх вихователів ЗДО до формування у старших дошкільників навичок щодо сталого розвитку Н. Миськова підкреслює, що процес формування особистості, виховання i навчання триває все життя, однак перевага надається дошкільній освіті як початковому етапу становлення особистості, але ж впровадження ідей сталого розвитку ускладнюється тим, що вони є відмінні від традиційної освіти.

Дослідниця підкреслює, що підготовка майбутніх вихователів до професійної діяльності $є$ організованим цілісним процесом, спрямованим на формування готовності діяти у швидкозмінних обставинах сучасного освітнього процесу дошкільної освіти, основою якої є засвоєння студентами базових професійних знань та вмінь, виховання особистісних і професійних якостей та цінностей. Майбутні фахівці орієнтуються на дії, що спрямовані на задоволення власних життєвих потреб, основою яких є ціннісне ставлення до природи, середовища, людей (Миськова, 2018).

Дослідниця С. Петренко в дослідженні вважає, що в контексті підготовки майбутніх вихователів до формування у дітей основних рухових умінь i навичок, вихователі нової генерації мають можливість організувати процес виховання дошкільників, інтенсивний розвиток якого відбувається в наші дні та має велике значення в процесі формування особистості дитини. Теоретичні основи та практична діяльність майбутнього вихователя пов'язана 3 удосконаленням процесу підготовки студентів до роботи з фізичного виховання 3 дошкільниками та підвищенням вимог до рівня його підготовки: правильне 
пояснення та демонстрація рухів вихователем, знання методики навчання рухів, надання практичної допомоги дітям та виправлення помилок тощо.

На основі аналізу різних підходів до проблеми дослідження автором визначено професійну підготовку майбутніх вихователів до формування у дошкільників основних рухових умінь i навичок як процес оволодіння необхідними теоретико-методичними знаннями, формування відповідних умінь і навичок, професійної спрямованості, розвиток професійних та особистісних якостей (Петренко, 2007).

Вивчаючи питання підготовки фахівців, здатних забезпечити розвиток дітей (потреб, інтересів, нахилів, здібностей), О. Попович зазначає про те, що конструктивна діяльність є основою становлення окремої особистості, яка поєднується зі швидко зростаючим інтелектом, абстрактним мисленням, логічністю, що відображається в дитячих виробах з будь-якого матеріалу (Попович, 2017).

Дослідниця вважає, що назріла потреба суспільства у формуванні компетентнісного фахівця дошкільної освіти 3 організації конструктивної діяльності, у змістовому та технологічному забезпеченні освітнього процесу, застосування засобів конструктивної діяльності в навчальному процесі та необхідністю розвитку у студентів предметного мислення, реалізацію можливостей студентів для розвитку їх креативних здібностей. Тому, підготовка майбутніх вихователів в даному контексті проявляється в необхідності володіння систематизованими знаннями вихованців у сфері фізіологічного та психічного розвитку, а також в пізнанні структури їх конструктивної діяльності (Попович, 2017).

I. Трубник, у свою чергу, еколого-педагогічну підготовку майбутнього вихователя розглядає як осягнення необхідності формувати потреби людини, пов'язані 3 природним оточенням (пізнавальні, емоційні, естетичні, комунікативні) та створення умов для розвитку мотиваційної сфери й закономірностей формування в дітей дошкільного віку екологічно мотивованої поведінки. Автор доводить, що тільки вихователь 3 розвиненою екологічною свідомістю, сформованою системою екологічних цінностей та пріоритетів, достатнім рівнем екологічної культури може повноцінно розвивати нове екологічне мислення дошкільнят та впливати на їхню поведінку.

Підготовка майбутніх вихователів здійснюється в Україні у різних типах навчальних закладів, однак, у ЗВО майбутні педагоги отримують достатньо високий рівень теоретичної та практичної еколого-педагогічної підготовки, яка забезпечує поєднання успішне засвоєння наук психолого-педагогічного циклу та формування вмінь еколого-педагогічної діяльності, а також вдосконалення професійної діяльності в процесі становлення особистості дошкільника, його екологічної культури, результатом якої $\epsilon$ екологічно мотивована поведінка. Взаємоконтакти вихователя i вихованця в еколого-педагогічній галузі $\epsilon$ складниками успішності їхньої діяльності: єднання 3 природою, моральна позиція у сучасному суспільстві (Трубник, 2009). 
На думку Т. Філімонової, проблеми підготовки майбутніх вихователів до патріотичного виховання дошкільників обумовлені: потребами суспільства, наявністю науково-методичного забезпечення, шаблонністю змісту освіти та специфічними завданнями підготовки студентів до патріотичного виховання дітей, сучасними вимогами до рівня підготовки майбутніх фахівців.

Дослідниця вважає, що виховання патріотизму, починаючи з дошкільного віку, $\epsilon$ значущим для нового покоління і $\epsilon$ результатом довготривалого виховного впливу. Патріотичне виховання потребує озброєння вихователів відповідним методичним інструментарієм і передбачає реалізацію таких груп завдань як: формування у студентів ставлення до патріотизму як до соціальноморальної цінності, інтересу до виховної діяльності, практичної підготовленості для здійснення виховної роботи.

Отже, автор визначає підготовку майбутніх вихователів ЗДО до патріотичного виховання дошкільнят як осмислений особистістю та сприйнятливий процес щодо формування у студентів готовності до здійснення національно-патріотичного виховання дітей, що набуває розвитку в результаті самоосвіти та професійного самовиховання майбутніх фахівців (Філімонова, 2019).

У контексті пошуку шляхів щодо вдосконалення програми підготовки вихователів нового покоління, які здатні створювати умови для розвитку дітей, C. Нечай акцентує увагу на проблемі удосконалення процесу підготовки майбутніх фахівців. Музичне виховання дошкільників відбувається завдяки успішній й систематичної взаємодії музичного керівника та вихователя. Гармонійна адаптація, соціалізація та творчий розвиток обумовлено вмінням вихованця розрізняти звуки, схарактеризувати їх, виділяти особливості.

Дослідниця зазначає, що музична підготовка майбутніх вихователів у ЗВО є складовою професійної підготовки фахівців системи дошкільної освіти. Зміни в підготовці сучасних фахівців 3 музичного виховання дошкільників пов'язані з підвищенням значення вищої освіти в суспільстві, використання нових програм і спецкурсів з музичного мистецтва в освітньому процесі, що спрямовані на розширення змісту підготовки фахівців. Однак, в основу підготовки мають бути покладені новий погляд майбутніх вихователів на розвиток і виховання дитини засобами музики та готовність їі використовувати як механізм у зміцненні соматичного, психічного і духовного здоров'я дитини (Нечай, 2015).

Як зазначає Ю. Волинець, дослідницька діяльність у ЗВО організовується викладачем на заняттях і спрямовується на здобуття нових знань шляхом проведення спостережень, дослідів, вимірювань відповідно до навчальних програм. Суть дослідницької діяльності майбутніх вихователів ЗДО полягає в спільній праці, пізнанні, спілкуванні та взаємодії суб'єктів, являє собою складний процес переходу студента від незнання до знання, від випадкових спостережень і розрізнених відомостей - до системи знань.

Так, лише під час роботи з інформаційними джерелами студент здійснює аналіз, конкретизацію, порівняння, систематизацію та узагальнення, оскільки 
знання наповнюються доступними для студента поняттями і стають більш стійкими. Таким чином, успішне оволодіння дослідницькими вміннями допоможе застосовувати здобуті знання, сучасні педагогічні досягнення, інноваційні технології у практичній діяльності 3 дітьми дошкільного віку (Волинець, 2015).

Т. Танько у своєму дослідженні визначила педагогічні умови та шляхи реалізації музично-педагогічної підготовки студентів факультету дошкільного виховання, що допомогло сформувати специфіку музично-педагогічної компетентності вихователя закладу дошкільної освіти, а музично-педагогічну компетентність розглядати як результат такої підготовки. Для забезпечення ефективності підготовки студентів необхідна цілісна організаційно-методична система щодо забезпечення розвитку майбутнього вихователя як творчої особистості, здатної до творчого самовираження (Танько, 2004).

Погоджуємося 3 думкою С. Гаврилюк, яка стверджує, що найактуальнішими нині $є$ глобальні перетворення інноваційного характеру в системі дошкільного навчання та виховання, висвітлюються питання нового характеру щодо підготовки педагогічних кадрів для закладів дошкільної освіти. Тому, необхідні кардинальні зміни у сфері професійної освіти майбутніх фахівців. Необхідні зміни у вищій школі, тому знання студентів мають відповідати високому рівню підготовки, відповідати новим критеріям. Кваліфікований, компетентний студент, який здатний до професійного росту, соціальної та фахової мобільності, має бути конкурентоздатним на ринку праці.

Науковець у своєму дослідженні зазначає про те, що питання підготовка майбутніх спеціалістів в умовах 3 ВО до педагогічної творчості розглядається як багатокомпонентний, цілеспрямований, довготривалий процес становлення творчої особистості педагога, який спроможний до майбутньої інноваційної діяльності в умовах сучасного ЗДО. Найважливішою складовою підготовки студентів до творчої діяльності $€$ знання про суть та механізми творчого процесу, характеристики творчої особистості, особливостей дитячої творчості.

Отже, проведений аналіз науково-педагогічних джерел щодо визначення суті поняття «підготовка майбутніх вихователів» підтверджує актуальність даного дослідження, оскільки освітній процес має бути організований 3 урахуванням сучасного стану дошкільної освіти.

Висновки. Узагальнення суті схарактеризованих основних понять дослідження дає можливість встановити, що підготовка майбутніх вихователів до роботи в ЗДО має спрямовуватися на забезпечення:

1) творчої взаємодії майбутнього вихователя 3 дитиною, iї розвитку, визначення напрямів діяльності в умовах ЗДО;

2) теоретичної підготовки студента в галузі дошкільної освіти;

3) практичної діяльності: планування та організація навчально-виховної роботи в ЗДО, володіння методами навчання і виховання дошкільнят.

Отже, поняття «підготовка майбутніх вихователів» доцільно розглядати як цілісний освітній процес, спрямований на формування здатності майбутніх вихователів до набуття знань, фахових умінь, професійного мислення, розвиток 
особистісних якостей, що стимулюватимуть їхній саморозвиток та самовдосконалення в майбутній професійній діяльності. Таким чином, розглянувши базові поняття дослідження, було уточнено термінологічний апарат щодо вивчення сутності досліджуваної проблеми.

Подальші перспективи розвідок вбачаємо в теоретичному обгрунтуванні компонентів підготовки майбутніх вихователів до професійної діяльності в закладах дошкільної освіти.

\section{Лimepamypa}

1. Бахіча Е. Е. Досвід підготовки майбутніх вихователів до професійної діяльності в полікультурному просторі Криму. Проблеми сучасної педагогічної освіти. Серія: Педагогіка і психологія. Ялта : РВВ КГУ, 2009. Вип. 21. Ч. 5. С. 122-126.

2. Бахіча Е. Е. Підготовка майбутніх вихователів дошкільних навчальних закладів до професійної діяльності в полікультурному середовищі Криму : автореф. дис. ... докт. пед. наук : 13.00.08. Одесса, 2011. 21 с.

3. Бутенко В. Г. Підготовка майбутніх вихователів до формування здоров’язбережувальної компетентності дошкільників засобами ігрової діяльності : автореф. дис. ... канд. пед. наук : 13.00.04. Суми, 2018. 23 с.

4. Бутенко В.Г. Сучасний стан підготовки майбутніх вихователів до формування здоров'язбережувальної компетентності дошкільників засобами ігрової діяльності. Науковий часопис НПУ імені М. П. Драгоманова. Серія 5 Педагогічні науки: реалї та перспективи. Київ: Вид-во НПУ імені М. П. Драгоманова, 2018. Вип. 62. С.22-34.

5. Вашак О. О. Підготовка майбутніх вихователів до екологічного виховання дошкільників на засадах етнопедагогіки : автореф. дис. ... канд. пед. наук : 13.00.04. Київ, 2010. 22с.

6. Вашак О.О. Специфіка підготовки майбутніх вихователів до екологічного виховання дошкільників на засадах етнопедагогіки. Педагогічні науки. Полтава, 2009. Вип. 2. С. 49-54.

7. Віттенберг К. Ю. Підготовка майбутніх вихователів засобами інформаційно-комунікаційних технологій до навчання дітей іноземних мов : автореф. дис. ... канд. пед. наук : 13.00.04. Вінниця, 2010. 23c.

8. Волинець Ю. О. Підготовка майбутніх вихователів дошкільних навчальних закладів до дослідницької діяльності. Підготовка майбутніх вихователів до роботи з дітьми дошкільного віку: компетентнісний підхід / За загальною редакцією Г. В. Бєлєнької, О. А. Половіної. К., 2015. С.194-217.

9. Гаврилюк С. М. Принципи розвитку педагогічної творчості майбутніх вихователів дітей дошкільного віку. Педагогічні науки: теорія, історія, інноваційні технологї. Суми: Вид-во СумДПУ імені А. С. Макаренка, 2015. № 2 (46). С. 303-314.

10.Гаврилюк С. М. Теоретико-методичні засади професійної підготовки майбутніх вихователів дошкільних навчальних закладів до педагогічної творчості : автореф. дис... д-ра пед. наук : 13.00.04. Умань, 2016. 31 с. 
11.Галаманжук Л.Л. Підготовка майбутніх дошкільних педагогів до комплексного використання творів пластичного мистецтва у професійній діяльності. Наукові записки Тернопільського національного педагогічного університету. Серія: Педагогіка. Тернопіль: ТНПУ, 2007. № 2. С. 14-17.

12.Галаманжук Л. Л. Підготовка майбутніх дошкільних педагогів до комплексного використання творів пластичного мистецтва у вихованні старших дошкільників : автореф. дис. ... канд. пед. наук : 13.00.04. Тернопіль, 2007. 22 с.

13.Грама Г. П. Підготовка майбутніх вихователів до формування елементарних математичних уявлень у дошкільників : автореф. дис. ... канд. пед. наук : 13.00.08. Одесса, 2010. 20 с.

14.Грама Г. П. Підготовка майбутнього вихователя до формування математичних уявлень у дошкільників. Науковий вісник Південноукраїнського державного педагогічного університету імені К. Д. Уиинського. Одесса: ПДПУ імені К. Д. Ушинського, 2007. Вип. 1-2. С. 111-117.

15.Давкуш Н. В. Зміст підготовки майбутніх вихователів дошкільних навчальних закладів: матеріали міжнародної науково-практичної конференції «Розвиток міжнародного співробітництва в галузі освіти у контексті Болонського процесу» (11-12 березеня 2010 р.). Ялта : РВНЗ КГУ, 2010. С. 5056.

16.Давкуш Н. В. Підготовка майбутніх вихователів дошкільних навчальних закладів до прогностичної діяльності : автореф. дис. ... канд. пед. наук : 13.00.04. Ялта, 2011. 20 с.

17.Дичківська I. М. Підготовка вихователя як суб'єкта інноваційної педагогічної діяльності в контексті сучасних тенденцій розвитку. Оновлення змісту, форм та методів навчання і виховання в закладах освіти. Рівне : РДГУ, 2004. Вип.29. С. 24-31.

18. Дичківська I. M. Теоретико-методичні засади підготовки майбутніх вихователів дошкільних закладів до інноваційної педагогічної діяльності : автореф. дис. ... докт. пед. наук : 13.00.04. Харків, 2018. 40 с.

19. Дяченко С. В. Зміст професійної підготовки майбутніх вихователів до формування основ комп'ютерної грамотності в старших дошкільників. Сучасні тенденції розвитку інформаційних технологій в науці, освіті та економіці: матеріали II Всеукр. наук.-практ. конф. (8-10 квітня 2008 р., м. Луганськ). Луганськ : Альма-матер, 2008. С. 116-118.

20. Дяченко С. В. Підготовка майбутніх вихователів до формування основ комп'ютерної грамотності старших дошкільників : автореф. дис... канд. пед. наук: 13.00.04. Луганськ, 2009. 20 с.

21.Смельянова Н. Л. Підготовка майбутніх вихователів до роботи над засвоєнням старшими дошкільниками народознавчої лексики : автореф. дис... канд. пед. наук: 13.00.04. Одесса, 2003. 21 с.

22. Смельянова Н. Л. Професійна діяльність як педагогічна проблема. Міжнародна науково-методична конференція «Теорія та практика управління педагогічним процесом». Одеса, 2002. С. 269-274. 
23.Залізняк А. М. Підготовка майбутніх вихователів до роботи з батьками 3 морального виховання дітей старшого дошкільного віку : автореф. дис... канд. пед. наук: 13.00.04. Київ, 2009. 22 с.

24.Залізняк А. М. Сучасний стан підготовки майбутніх вихователів до роботи з батьками з морального виховання дітей старшого дошкільного віку. Науковий часопис НПУ імені М. П. Драгоманова: Серія 16. Творча особистість учителя: проблеми теорії $і$ практики. Київ: НПУ імені М. П. Драгоманова, 2008. Вип. 8 (18). С. 106-109.

25.Захарасевич Н. В. Підготовка майбутніх вихователів до рольової діяльності дітей у дошкільних навчальних закладах : автореф. дис... канд. пед. наук: 13.00.04. Івано-Франківськ, 2018. 22 с.

26.Захарасевич Н. В. Професійна підготовка майбутніх вихователів дошкільних навчальних закладів: методологічні підходи. Гірська школа Украйнських Карпат. Івано-Франківськ, 2018. Вип. 18. С. 183-187.

27.Книш Т.В. Валеологічна підготовка майбутніх вихователів дошкільних закладів освіти : автореф. дис... канд. пед. наук: 13.00.04. Київ, 2001. 19 c.

28. Книш Т. В. Фізична підготовленість студентів - майбутніх вихователів дошкільних закладів освіти. Проблеми педагогічних технологій. Луцьк, 2000. Вип.1. С. 90-94.

29. Миськова Н. М. Підготовка майбутніх вихователів до використання технологій вітагенного навчання у формуванні навичок сталого розвитку у дітей дошкільного віку. Педагогіка та психологія: виклики і сьогодення: матеріали міжнар. наук.-практ. конф. (Київ, 4-5 трав. 2018 р.). Київ: ГО «Київська наукова організація педагогіки та психології», 2018. С. 49-51.

30.Миськова Н. М. Підготовка майбутніх вихователів закладів дошкільної освіти до формування у старших дошкільників навичок, орієнтованих на сталий розвиток : автореф. дис... канд. пед. наук: 13.00.04. Хмельницький, 2018. 23с.

31.Нечай С. П. Про підготовку майбутніх педагогів до музичного виховання дошкільників в умовах сучасної вищої освіти. Вісник Інституту розвитку дитини. Серія: Філософія, педагогіка, психологія. Київ: НПУ ім. М. П. Драгоманова, 2011. Вип. 17. С. 80-87.

32.Нечай С. П. Теорія і практика підготовки майбутніх вихователів до поліфункціонального застосування музики в аудіальному розвитку дошкільників : дис... докт. пед. наук: 13.00.08. Київ, 2015. 493с.

33. Петренко С. А. Підготовка майбутніх вихователів до формування у дітей дошкільного віку основних рухових умінь і навичок : автореф. дис... канд. пед. наук: 13.00.04. Київ, 2007. 21 с.

34.Петренко С. А. Творча діяльність педагога як важливий засіб формування у дошкільників основних рухових умінь та навичок. Вісник Київського міжнародного університету. Серія: Педагогічні науки. Київ: КиМУ, 2005. Випуск № 7. С. 186-195. 
35.Попович О. М. Основні категорії дослідження процесу підготовки майбутніх педагогів до організації конструктивної діяльності дітей. Педагогічні науки: теорія, історія, інновачійні технології. Суми : СумДПУ ім. А. С. Макаренка, 2013. № 6 (32). С. 216-222.

36. Попович О. М. Підготовка майбутніх вихователів до організації конструктивної діяльності дітей дошкільного віку : автореф. дис... канд. пед. наук: 13.00.04. Тернопіль, 2017. 24c.

37. Сорока О. Ю. Підготовка вчителів іноземної мови до роботи в дошкільному закладі. Удосконалення професійної підготовки вчителя початкових класів засобами дисциплін гуманітарного ииклу: матеріали Всеукраїнської науково-практичної конференції (Херсон, 25-26 жовтня 2005 року). Херсонськ. держ. ун-т. Херсон: Айлант, 2005. С.241-244.

38. Танько Т. П. Теорія та практика музично-педагогічної підготовки майбутніх вихователів дошкільних закладів у педагогічних університетах : автореф. дис... д-ра пед. наук: 13.00.04. Х., 2004. 41 с.

39.Трубник I. В. Підготовка майбутніх вихователів до формування екологічно мотивованої поведінки старших дошкільників : автореф. дис... канд. пед. наук: 13.00.04. Ялта, 2009. $23 \mathrm{c}$.

40.Трубник I. В. Професійно-екологічна компетентність вихователя дошкільного закладу. Збірник наукових праць Бердянського державного педагогічного університету (Педагогічні науки). Бердянськ : БДПУ, 2007. №3. C. 17-22.

41.Філімонова Т. В. Етапи підготовки майбутнього вихователя до патріотичного виховання дітей старшого дошкільного віку. Науковий часопис НПУ імені М. П. Драгоманова. Серія 5. Педагогічні науки: реалії та перспективи. Київ, 2018. Вип. 61. С. 306-310.

42.Філімонова Т. В. Підготовка майбутніх вихователів дошкільних навчальних закладів до патріотичного виховання дітей старшого дошкільного віку : автореф. дис... канд. пед. наук: 13.00.04. Кропівницький, 2019. 24 с.

\section{References}

1. Bakhicha, E. E. (2009). Dosvid pidhotovky maibutnikh vykhovateliv do profesiinoi diialnosti v polikulturnomu prostori Krymu [The experience of training of future educators for professional activities in the multicultural space of Crimea]. Problemy suchasnoi pedahohichnoi osvity - Problems of modern pedagogical education. Series: Pedagogy and psychology ,21, 122-126. Yalta (in Ukranian).

2. Bakhicha, E. E. (2011). Pidhotovka maibutnikh vykhovateliv doshkilnykh navchalnykh zakladiv do profesiinoi diialnosti $\mathrm{v}$ polikulturnomu seredovyshchi Krymu [Training of future educators of preschool educational institutions for professional activity in the multicultural environment of Crimea]. Extended abstract of candidate's thesis. Odessa (in Ukranian).

3. Butenko, V. H. (2018). Pidhotovka maibutnikh vykhovateliv do formuvannia zdoroviazberezhuvalnoi kompetentnosti doshkilnykiv zasobamy ihrovoi diialnosti [Training of future educators for the formation of health competence of 
preschoolers by means of play activities]. Extended abstract of candidate's thesis. Sumy (in Ukranian).

4. Butenko, V. H. (2018). Suchasnyi stan pidhotovky maibutnikh vykhovateliv do formuvannia zdorov'iazberezhuvalnoi kompetentnosti doshkilnykiv zasobamy ihrovoi diialnosti [The current state of training of future educators for the formation of health-preserving competence of preschoolers by means of play activities]. Naukovyi chasopys NPU imeni M. P. Drahomanova - Scientific journal of NPU named after M. P. Drahomanov. Series 5 Pedagogical sciences: realities and prospects,62, 22-34. Kyiv (in Ukranian).

5. Davkush, N. V. (2010). Zmist pidhotovky maibutnikh vykhovateliv doshkilnykh navchalnykh zakladiv [The content of training of future educators of preschool educational institutions]. Proceedings of the: mizhnarodna naukovopraktychna konferentsiia «Rozvytok mizhnarodnoho spivrobitnytstva $\mathrm{v}$ haluzi osvity $\mathrm{u}$ konteksti Bolonskoho protsesu» - International scientific-practical conference «Development of international cooperation in the field of education in the context of the Bologna process». (pp. 50-56). Yalta: RVNZ KHU (in Ukranian).

6. Davkush, N. V. (2011). Pidhotovka maibutnikh vykhovateliv doshkilnykh navchalnykh zakladiv do prohnostychnoi diialnosti [Training of future educators of preschool educational institutions for prognostic activity]. Extended abstract of candidate's thesis. Yalta (in Ukranian).

7. Diachenko, S. V. (2009). Pidhotovka maibutnikh vykhovateliv do formuvannia osnov kompiuternoi hramotnosti starshykh doshkilnykiv [Training of future educators for the formation of the basics of computer literacy of senior preschoolers]. Extended abstract of candidate's thesis. Luhansk (in Ukranian).

8. Diachenko, S. V. (2008). Zmist profesiinoi pidhotovky maibutnikh vykhovateliv do formuvannia osnov kompiuternoi hramotnosti $\mathrm{v}$ starshykh doshkilnykiv [The content of professional training of future educators to form the basics of computer literacy in senior preschoolers]. Proceedings of the: II Vseukr. nauk.-prakt. konf. «Suchasni tendentsii rozvytku informatsiinykh tekhnolohii v nautsi, osviti ta ekonomitsi» - Second Ukrainian Scientific and Practical Conference «Modern Trends in the Development of Information Technologies in Science, Education and Economics». (pp. 116-118). Luhansk: Alma-mater (in Ukranian).

9. Dychkivska, I. M. (2004). Pidhotovka vykhovatelia yak subiekta innovatsiinoi pedahohichnoi diialnosti $\mathrm{v}$ konteksti suchasnykh tendentsii rozvytku [Educator training as a subject of innovative pedagogical activity in the context of modern development trends]. Onovlennia zmistu, form ta metodiv navchannia $i$ vykhovannia $v$ zakladakh osvity - Update the content, forms and methods of teaching and education in educational institutions, 29, 24-31. Rivne : RDHU (in Ukranian).

10. Dychkivska, I. M. (2018). Teoretyko-metodychni zasady pidhotovky maibutnikh vykhovateliv doshkilnykh zakladiv do innovatsiinoi pedahohichnoi diialnosti [Theoretical and methodological principles of Training of future educators of preschool institutions for innovative pedagogical activity]. Extended abstract of Doctor's thesis. Kharkiv (in Ukranian). 
11. Filimonova, T. V. (2018). Etapy pidhotovky maibutnoho vykhovatelia do patriotychnoho vykhovannia ditei starshoho doshkilnoho viku [Stages of preparation of the future educator for patriotic education of children of senior preschool age]. Naukovyi chasopys NPU imeni M. P. Drahomanova. Seriia 5. Pedahohichni nauky: realii ta perspektyvy - Scientific journal of NPU named after MP Drahomanov. Series 5. Pedagogical sciences: realities and prospects, 61, 306-310. Kyiv (in Ukranian).

12. Filimonova, T. V. (2019). Pidhotovka maibutnikh vykhovateliv doshkilnykh navchalnykh zakladiv do patriotychnoho vykhovannia ditei starshoho doshkilnoho viku [Training of future educators of preschool educational institutions for patriotic education of children of senior preschool age]. Extended abstract of candidate's thesis. Kropivnytskyi (in Ukranian).

13. Halamanzhuk, L. L. (2007). Pidhotovka maibutnikh doshkilnykh pedahohiv do kompleksnoho vykorystannia tvoriv plastychnoho mystetstva $\mathrm{u}$ profesiinii diialnosti [Training of future preschool teachers for the integrated use of works of plastic art in professional activities]. Naukovi zapysky Ternopilskoho natsionalnoho pedahohichnoho universytetu. Seriia: Pedahohika - Scientific notes of Ternopil National Pedagogical University. Series: Pedagogy, 2, 14-17. Ternopil: TNPU (in Ukranian).

14. Halamanzhuk, L. L. (2007). Pidhotovka maibutnikh doshkilnykh pedahohiv do kompleksnoho vykorystannia tvoriv plastychnoho mystetstva $u$ vykhovanni starshykh doshkilnykiv [Training of future preschool teachers for the integrated use of works of plastic art in the education of senior preschoolers]. Extended abstract of candidate's thesis. Ternopil (in Ukranian).

15. Havryliuk, S. M. (2015). Pryntsypy rozvytku pedahohichnoi tvorchosti maibutnikh vykhovateliv ditei doshkilnoho viku [Principles of development of pedagogical creativity of future educators of preschool children]. Pedahohichni nauky: teoriia, istoriia, innovatsiini tekhnolohii - Pedagogical sciences: theory, history, innovative technologies, 2 (46), 303-314. Sumy (in Ukranian).

16. Havryliuk, S. M. (2016). Teoretyko-metodychni zasady profesiinoi pidhotovky maibutnikh vykhovateliv doshkilnykh navchalnykh zakladiv do pedahohichnoi tvorchosti [Theoretical and methodological principles of professional training of future educators of preschool educational institutions for pedagogical creativity]. Doctor's thesis. Uman (in Ukranian).

17. Hrama H. P. (2007). Pidhotovka maibutnoho vykhovatelia do formuvannia matematychnykh uiavlen $\mathrm{u}$ doshkilnykiv [Training of future educator for the formation of mathematical concepts in preschoolers]. Naukovyi visnyk Pivdennoukrainskoho derzhavnoho pedahohichnoho universytetu imeni K. D. Ushynskoho - Scientific Bulletin of the South Ukrainian State Pedagogical University named after K. D. Ushinsky, 1-2, 111-117. Odessa: PDPU imeni K. D. Ushynskoho (in Ukranian).

18. Hrama, H. P. (2010). Pidhotovka maibutnikh vykhovateliv do formuvannia elementarnykh matematychnykh uiavlen $\mathrm{u}$ doshkilnykiv [Training of 
future educators for the formation of elementary mathematical concepts in preschoolers. Extended abstract of candidate's thesis. Odessa (in Ukranian).

19. Knysh, T. V. (2000). Fizychna pidhotovlenist studentiv - maibutnikh vykhovateliv doshkilnykh zakladiv osvity [Physical fitness of students - future educators of preschool educational institutions]. Problemy pedahohichnykh tekhnolohii - Problems of pedagogical technologies, 1, 90-94. Lutsk (in Ukranian).

20. Knysh, T. V. (2001). Valeolohichna pidhotovka maibutnikh vykhovateliv doshkilnykh zakladiv osvity [Valeological training of future educators of preschool educational institutions]. Extended abstract of candidate's thesis. Kyiv (in Ukranian).

21. Myskova, N. M. (2018). Pidhotovka maibutnikh vykhovateliv do vykorystannia tekhnolohii vitahennoho navchannia u formuvanni navychok staloho rozvytku $\mathrm{u}$ ditei doshkilnoho viku [Training of future educators for the use of technologies of vitagenic learning in the formation of skills of sustainable development in preschool children]. Proceedings of the «Pedahohika ta psykholohiia: vyklyky i sohodennia» - International scientific-practical conference «Pedagogy and psychology: challenges and present». (pp.49-51). Kyiv: HO «Kyivska naukova orhanizatsiia pedahohiky ta psykholohii» (in Ukranian).

22. Miskova, N. M. (2018). Pidhotovka maibutnikh vykhovateliv zakladiv doshkilnoi osvity do formuvannia u starshykh doshkilnykiv navychok, oriientovanykh na stalyi rozvytok [Training of future educators of preschool institutions for the formation of skills in senior preschoolers focused on sustainable development]. Extended abstract of candidate's thesis. Khmelnytskyi (in Ukranian).

23. Nechai, S. P. (2011). Pro pidhotovku maibutnikh pedahohiv do muzychnoho vykhovannia doshkilnykiv $\mathrm{v}$ umovakh suchasnoi vyshchoi osvity [About preparation of future teachers for musical education of preschool children in the conditions of modern higher education]. Visnyk Instytutu rozvytku dytyny. Seriia: Filosofiia, pedahohika, psykholohiia - Bulletin of the Institute of Child Development. Series: Philosophy, pedagogy, psychology, 17, 80-87. Kyiv: NPU im. M. P. Drahomanova (in Ukranian).

24. Nechai, S. P. (2015) Teoriia i praktyka pidhotovky maibutnikh vykhovateliv do polifunktsionalnoho zastosuvannia muzyky $\mathrm{v}$ audialnomu rozvytku doshkilnykiv [Theory and practice of training of future educators for multifunctional application of music in audio development of preschoolers]. Doctor's thesis. Kyiv (in Ukranian).

25. Petrenko, S. A. (2005). Tvorcha diialnist pedahoha yak vazhlyvyi zasib formuvannia u doshkilnykiv osnovnykh rukhovykh umin ta navychok [Creative activity of a teacher as an important means of forming basic motor skills in preschoolers]. Visnyk Kyivskoho mizhnarodnoho universytetu. Seriia: Pedahohichni nauky - Bulletin of Kyiv International University. Series: Pedagogical sciences, 7, 186-195. Kyiv: KyMU (in Ukranian).

26. Petrenko, S. A. (2007). Pidhotovka maibutnikh vykhovateliv do formuvannia u ditei doshkilnoho viku osnovnykh rukhovykh umin i navychok [Training of future educators for the formation of basic motor skills in preschool children]. Extended abstract of candidate's thesis. Kyiv (in Ukranian). 
27. Popovych, O. M. (2013). Osnovni katehorii doslidzhennia protsesu pidhotovky maibutnikh pedahohiv do orhanizatsii konstruktyvnoi diialnosti ditei [The main categories of research of the process of training of future teachers for the organization of constructive activities of children]. Pedahohichni nauky: teoriia, istoriia, innovatsiini tekhnolohii - Pedagogical sciences: theory, history, innovative technologies, 6 (32), 216-222. Sumy: SumDPU im. A. S. Makarenka (in Ukranian).

28. Popovych, O. M. (2017). Pidhotovka maibutnikh vykhovateliv do orhanizatsii konstruktyvnoi diialnosti ditei doshkilnoho viku [Training of future educators for the organization of constructive activities of preschool children]. Extended abstract of candidate's thesis. Ternopil (in Ukranian).

29. Soroka, O. Yu. (2005). Pidhotovka vchyteliv inozemnoi movy do roboty v doshkilnomu zakladi [Training foreign language teachers to work in preschool]. Udoskonalennia profesiinoi pidhotovky vchytelia pochatkovykh klasiv zasobamy dystsyplin humanitarnoho tsyklu - Improving the professional training of primary school teachers by means of disciplines of the humanities: Proceedings of the Ukrainian scientific-practical conference, (pp. 241-244). Kherson (in Ukranian).

30. Tanko, T. P. (2004). Teoriia ta praktyka muzychno-pedahohichnoi pidhotovky maibutnikh vykhovateliv doshkilnykh zakladiv u pedahohichnykh universytetakh [Theory and practice of music-pedagogical training of future educators of preschool institutions in pedagogical universities]. Extended abstract of doctor's thesis. Kharkiv (in Ukranian).

31. Trubnyk, I. V. (2007). Profesiino-ekolohichna kompetentnist vykhovatelia doshkilnoho zakladu [Professional and ecological competence of a preschool teacher]. Zbirnyk naukovykh prats Berdianskoho derzhavnoho pedahohichnoho universytetu (Pedahohichni nauky) - Collection of scientific works of Berdyansk State Pedagogical University (Pedagogical Sciences), 3, 17-22. Berdiansk : BDPU (in Ukranian).

32. Trubnyk, I. V. (2009). Pidhotovka maibutnikh vykhovateliv do formuvannia ekolohichno motyvovanoi povedinky starshykh doshkilnykiv [Training of future educators for the formation of environmentally motivated behavior of older preschoolers]. Extended abstract of candidate's thesis. Yalta (in Ukranian).

33. Vashak, O. O. (2009). Spetsyfika pidhotovky maibutnikh vykhovateliv do ekolohichnoho vykhovannia doshkilnykiv na zasadakh etnopedahohiky [Specifics of training of future educators for ecological education of preschoolers on the basis of ethnopedagogy]. Pedahohichni nauky - Pedagogical sciences,2, 49-54. Poltava (in Ukranian).

34. Vashak, O. O. (2010). Pidhotovka maibutnikh vykhovateliv do ekolohichnoho vykhovannia doshkilnykiv na zasadakh etnopedahohiky [Training of future educators for ecological education of preschoolers on the basis of ethnopedagogy]. Extended abstract of candidate's thesis. Kyiv (in Ukranian).

35. Volynets, Yu. O. (2015). Pidhotovka maibutnikh vykhovateliv doshkilnykh navchalnykh zakladiv do doslidnytskoi diialnosti [Training of future educators of preschool educational institutions for research activities]. Pidhotovka maibutnikh vykhovateliv do roboty z ditmy doshkilnoho viku: kompetentnisnyi pidkhid 
- Preparing future educators to work with preschool children: a competency approach, (pp.194-217). Kyiv (in Ukranian).

36. Vittenberh, K. Yu. (2010). Pidhotovka maibutnikh vykhovateliv zasobamy informatsiino-komunikatsiinykh tekhnolohii do navchannia ditei inozemnykh mov [Training of future educators by means of information and communication technologies for teaching children foreign languages]. Extended abstract of candidate's thesis. Vinnytsia (in Ukrainian).

37. Yemelianova, N. L. (2002). Profesiina diialnist yak pedahohichna problema [Professional activity as a pedagogical problem]. Proceedings of the: Mizhnarodna naukovo-metodychna konferentsiia «Teoriia ta praktyka upravlinnia pedahohichnym protsesom» - International scientific-methodical conference «Theory and practice of pedagogical process management». (pp. 269-274). Odesa (in Ukranian).

38. Yemelianova, N. L. (2003). Pidhotovka maibutnikh vykhovateliv do roboty nad zasvoienniam starshymy doshkilnykamy narodoznavchoi leksyky [Training of future educators to work on mastering ethnographic vocabulary by senior preschoolers]. Extended abstract of candidate's thesis. Odessa (in Ukranian).

39. Zakharasevych, N. V. (2018). Profesiina pidhotovka maibutnikh vykhovateliv doshkilnykh navchalnykh zakladiv: metodolohichni pidkhody [Professional training of future educators of preschool educational institutions: methodological approaches]. Hirska shkola Ukrainskykh Karpat - Mountain school of the Ukrainian Carpathians, 18, 183-187. Ivano-Frankivsk (in Ukranian).

40. Zakharasevych, N. V. (2018). Pidhotovka maibutnikh vykhovateliv do rolovoi diialnosti ditei u doshkilnykh navchalnykh zakladakh [Training of future educators for the role activities of children in preschool educational institutions]. Extended abstract of candidate's thesis. Ivano-Frankivsk (in Ukranian).

41. Zalizniak, A. M. (2008). Suchasnyi stan pidhotovky maibutnikh vykhovateliv do roboty $\mathrm{z}$ batkamy $\mathrm{z}$ moralnoho vykhovannia ditei starshoho doshkilnoho viku [The current state of training of future educators to work with parents on the moral education of older preschool children]. Naukovyi chasopys NPU imeni M. P. Drahomanova: Seriia 16. Tvorcha osobystist uchytelia: problemy teorii i praktyky - Scientific journal of NPU named after MP Drahomanov: Series 16. Creative personality of a teacher: problems of theory and practice, 8 (18), 106-109. Kyiv: NPU imeni M. P. Drahomanova (in Ukranian).

42. Zalizniak, A. M. (2009). Pidhotovka maibutnikh vykhovateliv do roboty $z$ batkamy $\mathrm{z}$ moralnoho vykhovannia ditei starshoho doshkilnoho viku [Training of future educators to work with parents on the moral education of older preschool children]. Extended abstract of candidate's thesis. Kyiv (in Ukranian). 